\title{
Google Docs: Step by Step Sentence Construction for Primary School Marginal Passing Rate Pupils
}

\author{
Wong Pei Miin, Lee Yi Rou, Melor Md Yunus \\ Universiti Kebangsaan Malaysia, SJKC Serdang Baru 1, Selangor, Malaysia \\ Email: dorricewong@gmail.com, yirou87@gmail.com, melormy@gmail.com
}

How to cite this paper: Miin, W. P., Rou, L. Y., \& Yunus, M. M. (2019). Google Docs: Step by Step Sentence Construction for Primary School Marginal Passing Rate Pupils. Creative Education, 10, 237-245. https://doi.org/10.4236/ce.2019.102019

Received: December 28, 2018

Accepted: February 10, 2019

Published: February 13, 2019

Copyright (อ 2019 by author(s) and Scientific Research Publishing Inc. This work is licensed under the Creative Commons Attribution International License (CC BY 4.0).

http://creativecommons.org/licenses/by/4.0/

\section{(c) (7) Open Access}

\begin{abstract}
Writing is a form of communication to enable students to express their feelings and ideas in a constructed text. However, pupils are showing least interest to express their ideas in writing due to the non-contextualized materials and the traditional approach used in classroom. In order to arouse pupils' interest in writing, technology will be a tool for the teachers to achieve their goals. Google Docs, a free web-based platform, allows collaborative writing and cooperative learning to take place. This collaborative platform would gain pupils' understanding about the writing task and increase their interest in accomplishing the writing tasks. It also allows teachers to evaluate pupils' feedbacks and correspondingly for pupils to review on their peers' work. This study aims to explore the effectiveness of using Google Docs as a tool to carry out the 4-step sentence construction activities, which leads pupils progressively to expand their note from a word to a complete sentence based on the given title. It is specifically designed for the primary school pupils with marginal passing rate, which are categorised as the pupils with marginal passing grades. An action research based on Kemmis and Mc Tagart model was carried out with 30 GALUS pupils by gathering documents, survey questionnaires, interviews and assessments. The findings showed increase of 16 percent in the sentence construction skills among the pupils via the 4-step sentence construction activities conducted in Google Docs. The results also show that this approach clearly promotes the participation of pupils in writing activities. In conclusion, the 4-step sentence construction activities are effective in teaching sentence construction.
\end{abstract}

\section{Keywords}

Marginal Passing Rate Pupils, Google Docs, Sentence Construction, ESL Learner 


\section{Introduction}

P21's Framework for 21st Century Learning is developed to ensure that the learning of pupils is relevant to the globalisation of education. It highlights four outcomes which the pupils should be able to achieve in their study career, and which are life and career skills, learning and innovation skills, information and media and technology skills. In order to equip students with the 21 st century skills, they should be taught using the 21st century teaching approach (Pamela et al., 2016). Information and Communications Technology, ICT can be used as a learning tool in education and a powerful tool in enhancing the teaching and learning process (Yunus et al., 2013b); hence, it is coherent to the needs to improve the learning of English among ESL pupils, including the writing skills (Yunus, 2007).

However, less participation from the students is regarded as one of the existing challenges (Yunus et al., 2013a). Pupils are showing the least interest to express themselves in writing due to the non-contextualized materials, the traditional approach used in a classroom and the difference between the syntax in English and their first language. Based on the results obtained from the Malaysian Primary School Achievement Test in 2016, more than 23\% of pupils had failed in their English written paper "New UPSR Format Sees Big Drop in Straight A Scorers" (The Star Newspaper, 2016). It is proven that pupils are unable to write correctly in order to express their ideas.

The researchers also noticed that the pupils in their school, especially the primary Year 4 pupils (aged 10) are not performing in their examination as there is a wide transition gap between the Year 3 (aged 9) and the Year 4 exam formats. For Year 3, pupils are required to join sentence parts, fill in the blanks, and complete sentences with choices of answers given. As for Year 4, pupils are required to write stories and articles. There is a key problem with the pupils where they are unable to construct sentences correctly.

In order to elucidate this problem, the researchers employed Google Docs as a tool to carry out the 4-step sentence construction activities, which lead pupils progressively to expand their note from a word to a complete sentence based on the given titles. This collaborative platform gained pupils' understanding about the writing task and increased their interest in accomplishing the writing tasks. It also allowed teachers to evaluate pupils' feedbacks and correspondingly for pupils to review on their peers' work. This study aimed to explore the effectiveness of the 4-step sentence construction activities via Google Docs to improve the pupils' performance and interest in constructing sentences.

\section{Literature Review}

\subsection{Google Docs}

Information and Communications Technology can be regarded as an important tool to enhance the teaching of writing skills (Yunus, 2007). With the rise of Google in recent decades, it is no surprise that many are using Google Docs, 
even in the classrooms as it operates in the cloud with no download faulty, troublesome maintenance or expensive yearly upgrades required. It is easy to share documents with other people, making collaboration between writers easier and quicker by using Google Docs (Ebener, 2017).

It promotes cooperative learning where it increases interactions among pupils and facilitate the peer feedback process (Suwantarathip, 2014). Google Docs makes a platform which enables pupils receive immediate feedback and allows advanced-level pupils to generate ideas that work as references to the weaker pupils. For instance, high proficient pupils would answer the tasks assigned by their teachers and followed by low proficient pupils after referring to the peers' answers. Pupils can easily edit their answers and work without restrictions.

\subsection{Importance of Interest in Writing}

Writing enables students to express their feelings and ideas in a constructed text. The integration of ICT in the teaching of writing was said to encourage learners' independence and self-discovery skills (Yunus et al., 2013c). Hidi \& Renninger (2006) defined that interest for writing is required as it determines the way that pupils approach writing and it affects the results they achieve. Pupils who are interested in writing are more likely to set goals effectively, make use of useful strategies, and seek feedback as they work with writing tasks (Lipstein \& Renninger, 2007).

In 1913, John Dewey claimed that both interest and effort are oppositional and complementary. For instance, pupils find it easy to accomplish a task that takes hours to complete as they are motivated to complete the task. However, a simple task which takes a shorter duration to complete might be a burden to the pupils when they are not so keen on giving attention to the task; hence, being interested in writing is the core principle to acquire the skill.

\subsection{Self Determination Theory}

Self-Determination Theory (SDT) is a swiftly growing theory of motivation which addresses individuals' initiation of behaviour (Grolnick, 2015). SDT suggests that human motivation can be classified into two main categories namely intrinsic motivation and extrinsic motivation.

An intrinsically motivated pupil "is one whose involvement and maintenance in the activity happens as a result of the task itself because it is interesting and creates satisfaction; students with this type of motivation work on activities because they consider them pleasant" (Siqueira \& Wechsler, 2006). Pupils are motivated to involve in writing activities since Google Docs is a tool which successfully aroused their interest and enhanced their sentence construction skills.

On the other hand, extrinsically motivated pupils "is one who performs a task or activity because they are interested in social or external rewards, external recognition, praise or just avoiding punishment" (Siqueira \& Wechsler, 2006). Pupils in this study received immediate feedback from teachers and peers while 
constructing phrases and sentences in Google Docs. The compliments from both teachers and peers helped to elevate their interest and motivation in writing.

\section{Methodology}

This study adapted an action research framework suggested by Kemmis and McTaggart (2005). The framework (Figure 1) consists of six stages to be carried out. Firstly, the authors identified the existing problem that needed to be studied on. In the present research, it is the low achievement in sentence constructions among primary school pupils. Thirty pupils with marginal passing rate were selected through purposive sampling method based on their previous exam result. In stage two, the authors planned to utilise Google Docs as a tool to carry out the 4-step sentence construction activities, which scaffolded pupils progressively to expand their note from a word, phrase, simple sentence and finally to a complete compound sentence based on the given title. Besides, the 4-step activities are differentiated with different colours, red, yellow, blue and green. The pupils would need to complete each and every step and their answers would be reviewed by the teachers before moving on to the next step. In stage three, the interventions were implemented and the pupils had completed the sentence construction tasks in Google Docs. The data was collected in stage four through questionnaire, interviews and pre and post-test and later analysed in stage five. The questionnaire which consists of sixteen items was used to identify the interest of pupils in writing and the problems they faced in writing. Interviews which consist of six questions had been conducted twice in this study, which were before and after the implementation of the 4-step sentence construction activities. The interviews were later transcribed and used to further explain the data obtained throughout the study. As for the pre and post-test, pupils were required to write ten sentences based on the notes given and awarded ten marks for each correct sentence. The results of the tests had been tabulated and the mean scores are used to compare the results of both the tests. A paired two sample t-test was also conducted to identify the difference between means for the pre-test and the post-test. In the final stage, the authors have reflected on the efficacy of the 4-steps sentence construction activities via Google Docs in increasing the pupils' sentences construction abilities and promoting their interest in writing.

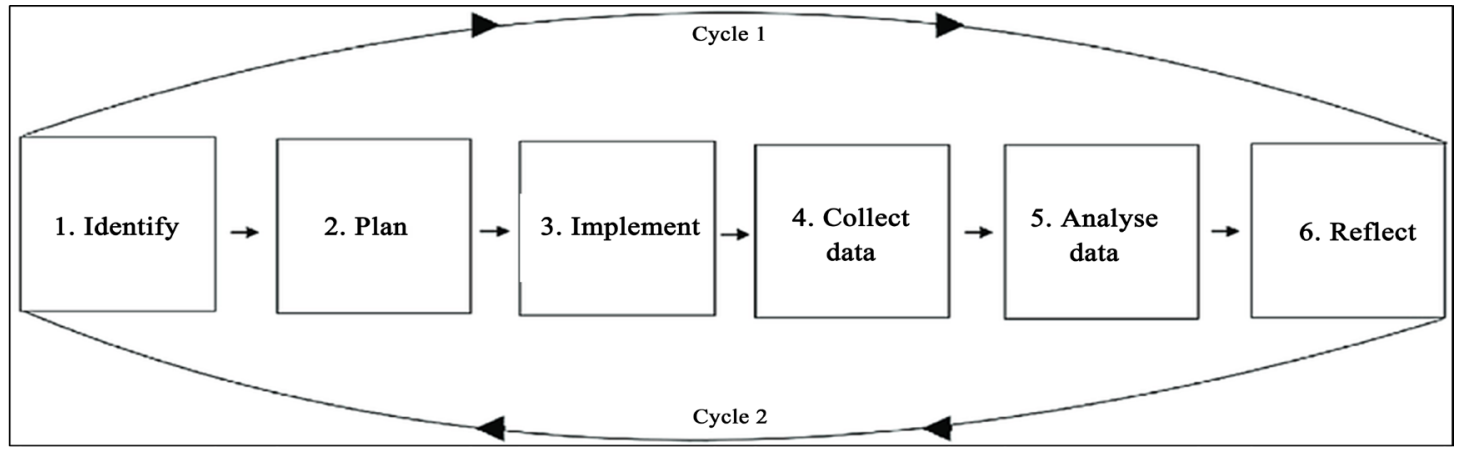

Figure 1. Action Research Framework adapted from Kemmis and McTaggart (2005). 


\section{Findings and Discussion}

\subsection{Performance of Pupils in Constructing Sentences}

Pre-test and post-test were conducted before and after the use of 4-step sentence construction activities to measure the achievement of the pupils in constructing sentences. The results of the tests were analysed and presented in the form of means. The means of the tests were compared. Inferential data analysis had also been carried out to identify the significant difference between the results.

Figure 2 shows the mean for both pre-test and post-test. For pre-test, pupils obtained total marks of 910 with mean score of 30.3. For post-test, pupils obtained 1390 marks with mean score of 46.3 . The rise of 16 mean score or an increment of 16 percent indicates the 4 -step sentence construction activities conducted via Google Docs did help to improve pupils' writing abilities.

As suggested by Riffenburgh (2012), Shapiro-Wilk test can be used to test the normality of a distribution when the sample size, $\mathrm{n}<50$. Since there were only 30 samples in this study, Shapiro-Wilk test has been conducted as shown in Table 1 and the data collected are normal with sig. $=0.037$ for pre-test and sig. $=$ 0.268 for post-test, $p>0.05$.

Later, paired two sample t-test has also been done as shown in Table 2 to compare the difference between means for pre-test and post-test. According to Kitchin \& Tate (2013), $p<0.05$ would indicate a significant result and often termed "highly significant". The study shown significant difference between means for pre-test and post-test with $\mathrm{t}(29)=-11.379, p<0.05$.

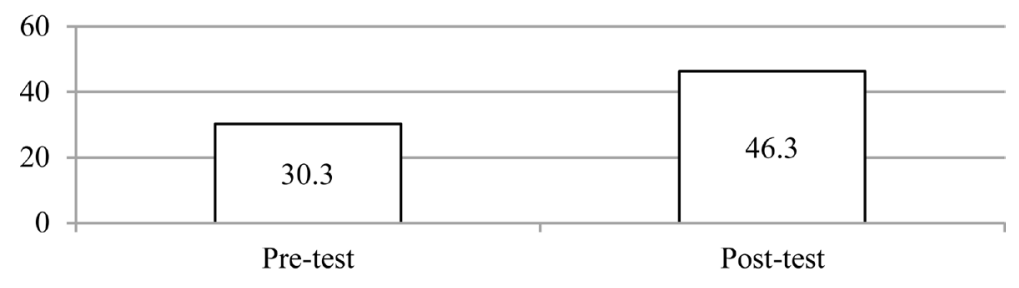

Figure 2. Comparison of mean between pre test and post test.

Table 1. Test of normality for pre and post test.

\begin{tabular}{rccc}
\hline & \multicolumn{3}{c}{ Shapiro-Wilk } \\
\cline { 2 - 4 } & Statistic & $\mathrm{df}$ & Sig. \\
\hline Pre-test & 0.925 & 30 & 0.037 \\
Post-test & 0.958 & 30 & 0.268 \\
\hline
\end{tabular}

Table 2. Paired sample t-test for pre and post test.

\begin{tabular}{ccccccc}
\hline & \multicolumn{5}{c}{ Paired Differences } \\
\cline { 2 - 7 } & Mean & $\begin{array}{c}\text { Std. } \\
\text { Deviation }\end{array}$ & Std. Error Mean & t & df & $\begin{array}{c}\text { Sig. } \\
(2 \text {-tailed })\end{array}$ \\
\hline Pair 1 Pretest-Posttest & -16.00 & 7.70 & 1.41 & -11.38 & 29 & 0.000 \\
\hline
\end{tabular}


In other words, the pupils' performance in constructing sentences before the implementation of the 4-step sentence construction activities was at a dissatisfactory level where most of the pupils could not construct sentences correctly. After the implementation of the 4-step sentence construction activities via Google Docs, the pupils showed significant improvement in constructing sentences. This was mainly due to two reasons.

First of all, "written corrective feedback helps students to acquire and demonstrate mastery in the use of targeted linguistic forms and structures", (Bitchener \& Knoch, 2008). The immediate feedback provided by the teachers throughout the 4-step sentence construction activities helped the pupils to realise their mistakes and to make correction accordingly. They were given the opportunity to check on their answers given on every step before progressing to the next step. This means the pupils had acquired the skill of expanding words to phrases before constructing the sentences and eventually leading them to construct correct sentences.

Secondly, the pupils were given the opportunity to refer to their peers' answers as the 4-step sentence construction activities were conducted in Google Docs with all of the pupils accessing to the same document. According to Warnick (2008), humans tend to learn through imitation by observing certain patterns and practice on it. In this case, the low achievers tend to imitate the work of the high achievers but at the same time, they learnt on the method of constructing sentences slowly. At the end of the activities, they were able to construct sentences individually. In a nutshell, the 4-step sentence construction activities are indeed useful to enhance the sentence construction skills among the pupils.

\subsection{Interest of Pupils in Writing}

A pre-activity questionnaire had been distributed to the pupils and the results are as followed:

\begin{tabular}{|c|c|c|c|c|}
\hline No. & Item & $\begin{array}{l}\text { Agree } \\
\text { (f) }\end{array}$ & $\begin{array}{c}\text { Unsure } \\
\text { (f) }\end{array}$ & $\begin{array}{c}\text { Disagree } \\
\text { (f) } \\
0 \%\end{array}$ \\
\hline & & & & \\
\hline \multirow{2}{*}{1} & \multirow{2}{*}{ I enjoy writing in English. } & 5 & 15 & 10 \\
\hline & & 16.7 & 50 & 33.3 \\
\hline \multirow{2}{*}{2} & \multirow{2}{*}{ I enjoy writing on papers. } & 3 & 18 & 9 \\
\hline & & 10 & 60 & 30 \\
\hline \multirow{2}{*}{3} & \multirow{2}{*}{ I enjoy writing online. } & 19 & 7 & 4 \\
\hline & & 63.3 & 23.3 & 13.3 \\
\hline \multirow{2}{*}{4} & \multirow{2}{*}{ I always like the titles given by teachers. } & 4 & 21 & 5 \\
\hline & & 13.3 & 70 & 16.7 \\
\hline \multirow{2}{*}{5} & \multirow{2}{*}{ I like to write based on interesting titles. } & 11 & 13 & 6 \\
\hline & & 36.7 & 43.3 & 20 \\
\hline \multirow{2}{*}{6} & \multirow{2}{*}{ I only write when my teachers ask me to do so. } & 17 & 2 & 11 \\
\hline & & 56.6 & 6.7 & 36.7 \\
\hline
\end{tabular}




\begin{tabular}{|c|c|c|c|c|}
\hline \multicolumn{5}{|c|}{ Continued } \\
\hline \multirow{2}{*}{7} & \multirow{2}{*}{ I feel happy when I can write sentences correctly. } & 23 & 6 & 1 \\
\hline & & 76.7 & 20 & 3.3 \\
\hline \multirow{2}{*}{8} & \multirow{2}{*}{ I feel sad when I cannot write the sentences correctly. } & 22 & 6 & 2 \\
\hline & & 73.3 & 20 & 6.7 \\
\hline \multirow{2}{*}{9} & \multirow{2}{*}{$\begin{array}{l}\text { I always use the notes given by teachers to write } \\
\text { sentences. }\end{array}$} & 14 & 11 & 5 \\
\hline & & 46.6 & 36.7 & 16.7 \\
\hline \multirow{2}{*}{10} & \multirow{2}{*}{$\begin{array}{l}\text { I understand all the notes given by teachers when } \\
\text { writing sentences. }\end{array}$} & 3 & 6 & 21 \\
\hline & & 10 & 20 & 70 \\
\hline \multirow{2}{*}{11} & \multirow{2}{*}{ I skip the words that are new to me. } & 15 & 9 & 6 \\
\hline & & 50 & 30 & 20 \\
\hline \multirow{2}{*}{12} & \multirow{2}{*}{ I can write short sentences ( 3 - 6 words). } & 24 & 0 & 6 \\
\hline & & 80 & 0 & 20 \\
\hline \multirow{2}{*}{13} & \multirow{2}{*}{ I can write long sentences ( 7 - 15 words). } & 9 & 8 & 13 \\
\hline & & 30 & 26.7 & 43.3 \\
\hline \multirow{2}{*}{14} & \multirow{2}{*}{ I think writing in English is very difficult. } & 25 & 1 & 4 \\
\hline & & 83.3 & 3.3 & 13.3 \\
\hline \multirow{2}{*}{15} & \multirow{2}{*}{ I know the structure of sentences. } & 2 & 13 & 15 \\
\hline & & 6.7 & 43.3 & 50 \\
\hline \multirow{2}{*}{16} & \multirow{2}{*}{ I can use verb and adjectives in writing sentences. } & 4 & 14 & 12 \\
\hline & & 13.3 & 46.6 & 40 \\
\hline
\end{tabular}

Based on the results derived from the questionnaire, $10 \%$ of pupils who enjoy writing on papers were starkly juxtaposed with $63.3 \%$ of them who enjoyed writing online. It is shown that the use of technology and online platform is able to engage their interest in writing activities. For instance, one of the pupils stated that, "I like to post words online". Besides, $70 \%$ of the pupils had limited vocabulary and more than $50 \%$ of them had limited knowledge in sentence structures which made them failed in constructing correct sentences. As reflected by one of the pupils in his interview, "I could not think of the right word to use in English when I write". Another pupil also mentioned that, "I can think of the sentence in Chinese but not in English, it's hard".

Apart from that, a post-activity interview was conducted. One of the pupils commented that, "Now I think that writing a sentence is easy", "I think I can write sentences now", commented by another pupil. Also, pupils agreed that they feel more confident in writing sentences when they are guided step by step from expanding a word to a complete sentence.

Last but not least, they also expressed that it is easier and more interesting to write when they use Google Docs as they can view and take their peers' answers as references. "It is interesting to write in different colours. I can look at my friends' answer", commented by one of the pupils. The other pupil also mentioned that, "I think I can try to write more sentences using the steps". The findings are coherent with Shyamlee and Phil's (2012) findings which concluded that it is true that one of the ultimate goals of multimedia language teaching is to promote pupils' motivation and learning interest, which can be a practical way 
to get them involved in the language learning.

\section{Conclusion}

The results from the study have clearly shown that the 4-step sentence construction activities are indeed a benefitting teaching tool. Google Docs has enabled pupils with marginal passing rate to construct sentences as they refer to their peers' answers and hence, it improved their writing abilities through imitations. The results of the study are also coherent with the findings from Kuimova and Zvekov (2016) where technology "helps to increase learning interest, develop writing skills and promote communication skills".

However, there are certain loopholes of using this tool that need to be taken into consideration. First and foremost, pupils' English proficiency level, prior knowledge in using Google Docs should be taken into account when employing the activities. Secondly, since this study was conducted in a primary school in Malaysia, the results might differ if the 4-steps sentence construction activities are conducted in other institutions. Hence, further study could be done to longitudinally examine the use of Google Docs to improve pupils' writing skills.

\section{Implication}

The 4-step sentence construction activity guide had been uploaded in https://www.teacherspayteachers.com/ so it would be beneficial to the education field and the society. It also has the commercialisation potential for heavy-workloaded teachers and tight-scheduled parents where these materials could be easily downloaded from the given website; thus resolving time constraints and resources limitations issues in planning activities for teaching sentence constructions.

\section{Acknowledgements}

The authors would like to express gratitude to anonymous pupils who took part in the present study and to the reviewers for their helpful comments on an earlier draft of this paper.

\section{Conflicts of Interest}

The authors declare no conflicts of interest regarding the publication of this paper.

\section{References}

Bitchener, J., \& Knoch, U. (2008). The Value of Written Corrective Feedback for Migrant and International Students. Language Teaching Research, 12, 409-431.

https://doi.org/10.1177/1362168808089924

Dewey, J. (1933). How We Think. Boston: D. C. Heath and Company.

Ebener, S. (2017). Using Google Tools to Enhance Secondary Writing Instruction. Graduate Research Papers, Cedar Falls: University of Nothern Iowa. 
Grolnick, W. (2015). Mothers' Motivation for Involvement in Their Children's Schooling: Mechanisms and Outcomes. Motivation and Emotion, 39, 63-73. https://doi.org/10.1007/s11031-014-9423-4

Hidi, S., \& Renninger K. A. (2006). The Four-Phase Model of Interest Development. Educational Psychologist, 41, 111-127. https://doi.org/10.1207/s15326985ep4102_4

Kemmis, S., \& McTaggart, R. (2005). Participatory Action Research: Communicative Action and the Public Sphere. Thousand Oaks, CA: Sage Publications.

Kitchin, R., \& Tate, J. T. (2013). Conducting Research in Human Geography: Theory, Methodology and Practice. London: Routledge Taylor and Francis Group. https://doi.org/10.4324/9781315841458

Kuimova, M. V., \& Zvekov, O. D. (2016). Blogs as a Means to Enhance Writing Skills in EFL Classes. International Journal of Emerging Technologies in Learning (iJET), 11, 157-160. https://doi.org/10.3991/ijet.v11i04.5430

Lipstein, R. L., \& Renninger, K. A. (2007). Writing and Motivation. Amsterdam: Elsevier.

Pamela, L. M. S., Yunus, M. M., \& Mohamad, M. (2016). The Malaysian Education Blueprint 2013 and Its Effects on English Language Teaching in Malaysia. Asian EFL Journal, 4, 158-171.

Riffenburgh, R. H. (2012). Statistics in Medicine. California: Elsevier.

Shyamlee, S. D., \& Phil, M. (2012). Use of Technology in English Language Teaching and Learning: An Analysis. In International Conference on Language, Medias and Culture (pp. 150-156). Singapore: IACSIT Press.

Siqueira, L. G. G., \& Wechsler, S. M. (2006). Motivação para a aprendizagem escolar: Possi-bilidades de medida. Avaliação Psicológica, Porto Alegre, 5, 21-3.

Suwantarathip, O. (2014). The Effects of Collaborative Writing Activity Using Google Docs on Students' Writing Abilities. The Turkish Online Journal of Educational Technology, 13, 148-156.

The Star Newspaper (2016). New UPSR Format Sees Big Drop in Straight A Scorers. https://www.thestar.com.my/news/nation/2016/11/18/new-upsr-format-sees-big-dropin-straight-a-scorers/

Warnick, B. R. (2008). Imitation and Education: A Philosophical Inquiry into Learning by Example. New York: State University of New York.

Yunus, M. M. (2007). Malaysian ESL Teachers' Use of ICT in their Classrooms: Expectations and Realities. ReCALL, 19, 79-95. https://doi.org/10.1017/S0958344007000614

Yunus, M. M., Lau, J. K. T., \& Salehi, H. (2013a). Using Blogs to Promote Writing Skill in ESL Classroom. In Proceedings of the 4th International Conference on Education and Educational Technologies (pp. 109-113).

https://www.researchgate.net/publication/236946577_Using_Blogs_to_Promote_Writi $\underline{\text { ng_Skill_in_ESL_Classroom }}$

Yunus, M. M., Nordin, N., Salehi, H., Embi, M. A., \& Mahamod, Z. (2013b). Managing Problems and Planning Activities Involving ICT Tools in Teaching ESL Reading and Writing. Asian Social Science, 9, 222-230. https://doi.org/10.5539/ass.v9n10p222

Yunus, M. M., Nordin, N., Salehi, H., Embi, M. A., \& Salehi, Z. (2013c). The Use of Information and Communication Technology (ICT) in Teaching ESL Writing Skills. English Language Teaching, 6, 1-8. https://doi.org/10.5539/elt.v6n7p1 